\title{
First report of leaf spot caused by Albifimbria verrucaria on spinach in Pakistan
}

\author{
Abdul Rehman ${ }^{1} \cdot$ Saira Mehboob ${ }^{2} \cdot$ Muhammad Waqar Alam $^{3}$ (D) Sumera Naz $^{2}$
}

Received: 21 November 2020 / Accepted: 26 February 2021 / Published online: 1 March 2021

(c) Società Italiana di Patologia Vegetale (S.I.Pa.V.) 2021

Keywords Leaf spot $\cdot$ Pathogenicity $\cdot$ Myrothecium verrucaria

Spinach (Spinacia oleracea L.) is one of the most widely cultivated and highly consumed vegetable in Pakistan. In autumn 2019, leaf symptoms such as small, round, and darkbrown spots (3-4 $\mathrm{mm}$ in diameter) were observed in multiple fields of "Okara"- a region of Punjab Province. At later stages, the lesions enlarged, coalesced and became water soaked. Small, black, sclerotium like bodies ( $1.5 \mathrm{~mm}$ in diameter) were produced on the leaf surface under moist conditions. Disease incidence was estimated at approximately 50\%. Excised segments $\left(1 \mathrm{~mm}^{2}\right)$ of symptomatic leaves were surfacedisinfected with sterile distilled water for $30 \mathrm{~s}$, and $1 \%$ sodium hypochlorite for $1 \mathrm{~min}$, then rinsed twice in sterile distilled water, placed on malt extract agar (MEA), and incubated at $25^{\circ} \mathrm{C}$ for 5 to 7 days. A slow-growing white fungus with black sporodochia (1.3-1.8 $\mathrm{mm}$ in diameter) was obtained after 8-10 days. The culture produced aseptate, hyaline, one-celled and cylindrical conidia ( 3 to $6 \times 2.0$ to $2.8 \mu \mathrm{m}$ ). On the basis of morphological and cultural characteristics, the pathogen was tentatively identified as Albifimbria verrucaria (Alb. \& Schewein.) L. Lombard \& Crous. (ex Myrothecium verrucaria (Alb. \& Schwein.) (Belisario et al. 1999). For molecular confirmation, the internal transcribed spacer (ITS) region of a representative isolate (PDL 2022) was amplified using primers ITS1F and ITS4 (Gardes and Bruns 1993) and sequenced. The ITS sequence of the isolate PDL 2022 (GenBank accession No. MW276146) showed $99 \%$ to $100 \%$ homology with Albifimbria verrucaria (GenBank accession Nos. FJ235085.1

Muhammad Waqar Alam

waqar.alam@imbb.uol.edu.pk

1 Department of Plant Pathology, University of Agriculture, Faisalabad 38040, Pakistan

2 Plant Pathology Research Institute, Ayub Agricultural Research Institute Faisalabad, Punjab 38000, Pakistan

3 Institute of Molecular Biology and Biotechnology, The University of Lahore, Lahore, Pakistan and KY582146.1). The culture was deposited in First Culture Bank of Pakistan. To test the pathogenicity, spore suspension $\left(1 \times 10^{6}\right.$ spores $\left./ \mathrm{ml}\right)$ was prepared from a 2 -week-old culture and applied to healthy, surface-disinfected leaves of spinach (cv. Local Sindhi) grown in pots with a handheld spray bottle. Control plants were inoculated with distilled water. Plants were kept covered with plastic bags for 5 days. After 7 days, spots similar to those observed on naturally infected plants were observed whereas noninoculated control plants remained asymptomatic. The fungus was reisolated consistently from symptomatic leaves, thus completing Koch's postulates. Previously, the pathogen has been reported to cause leaf spot of maize in Pakistan (Saira et al. 2017). To the best of our knowledge, this is the first report of spinach leaf spot caused by $A$. verrucaria in Pakistan. The disease could represent a threat to spinach crop. Therefore, disease management options should be explored.

\section{References}

Belisario A, Forti E, Corazza L, Kesteren HA (1999) First report of Myrothecium verrucaria from muskmelon seeds. Plant Pathol 83:589

Gardes M, Bruns TD (1993) ITS primers with enhanced specificity for basidiomycetes-Application to identification of mycorhizae and rusts. Mol Ecol 2:113-118

Saira M, Rehman A, Gleason ML, Alam MW, Muhammad S, Idrees M (2017) First Report of Myrothecium verrucaria Causing Leaf Spot of Maize in Pakistan. Plant Dis 101:1050

Publisher's Note Springer Nature remains neutral with regard to jurisdictional claims in published maps and institutional affiliations. 